\title{
ERRATA
}

\section{THE EMERGING FIELD OF LIPIDOMICS}

Markus R. Wenk

Nature Reviews Drug Discovery 4, 594-610 (2005)

Figure 1 contained errors; a corrected version of this figure is now available online on the final page of the article PDF

\section{ANTI-ANGIOGENICS STEAL THE SHOW}

Nature Reviews Drug Discovery 4, 448-449 (2005)

In a news in brief article, the development of PTK/ZK was credited to 'Novartis/Schering Plough'. PTK/ZK is in fact co-developed by Schering AG. 